\title{
IAMJ
}

INTERNATIONAL

AYURVEDIC

MEDICAL JOURNAL

dot $\odot$ @

Review Article

ISSN: 2320-5091

Impact Factor: 6.719

\section{ROLE OF AMALAKI RASAYAN AS AN ANTIOXIDANT IN OXIDATIVE STRESS}

\section{Kshirsagar Shubhangi Sureshkumar*1 Anjali D. Turale², Mangesh Hedau ${ }^{3}$, Ashish Jaiswal ${ }^{4}$}

${ }^{1}$ Assistant Professor, Department of Swasthavritta \& Yoga, Dr. Rajendra Gode Ayurved College, Hospital \& Research Center, Amaravati, Maharashtra, India

${ }^{2}$ Assistant Professor, Department of Swasthavritta \& Yoga, M.S. Ayurvedic Medical College, Kudwa, Gondiya, Maharashtra, India

${ }^{3}$ Ayurved and Panchakarma Consultant, Shashwat Ayurved and Panchakarma Clinic, Amravati, Maharashtra, India

${ }^{4}$ Assistant Professor, Department of Rachana Sharir, Dr. Rajendra Gode Ayurved College, Hospital \& Research Center, Amaravati, Maharashtra, India

Corresponding Author: drssksagar@gmail.com

https://doi.org/10.46607/iamj3009102021

(Published Online: October 2021)

\section{Open Access}

(C) International Ayurvedic Medical Journal, India 26021

Article Received: 26/09//2021 - Peer Reviewed: 07/10/2021 - Accepted for Publication: 08/10/2021

\section{Check for updates}

\begin{abstract}
Ayurveda is the science of life. The main aim of Ayurveda is to maintain the health of a healthy person and to cure the diseased person. For the maintenance of the health of a healthy person, rasayan chikitsa is advised in Ayurveda. Rasayan chikitsa is the separate branch of Ayurveda, which deals with various aspects of preventive health care. In today's modern era, the incidence of lifestyle disorders like hypertension, obesity, diabetes mellitus and cardiovascular diseases increased, because of altered dietary and living patterns. Oxidative stress may be responsible for most of the diseases. Lack of dietary antioxidants supplements and generation of free radicals induces disease associated with oxidative stress. Oxidative stress is essentially an imbalance between the production of free radicals and the ability of the body to counteract or detoxify their harmful effects through neutralization by antioxidants. Free radicals contain unpaired electrons, and they are unstable and highly reactive. They donate or accept an electron from other molecules, therefore behaving as oxidants. An antioxidant is a stable molecule, enough to donate an electron to rampaging free radical and neutralize it, thus reducing its capacity to damage. Ac-
\end{abstract}


cording to Ayurveda, Amalaki is the best rasayan, tridoshhar. As per modern science, it contains the largest amount of vitamin C (6oomg), and vitamin $\mathrm{C}$ has the best antioxidant property. Amalaki rasayan plays an important role as an antioxidant and thus relives oxidative stress, thus helpful in the prevention of many diseases.

Keywords: Rasayan, antioxidant, free radicals, Amalaki

\section{INTRODUCTION}

Health is the state of complete physical, mental and social wellbeing and not merely the absence of disease $^{[1]}$. Rasayan chikitsa is beneficial for the maintenance of health. As said, that, prevention is better than cure. Rasayan is a substance that decreases the ageing process, increases longevity, increase mental and physical strength and destroys disease ${ }^{[2]}$.

Due to modernization, the dietary habits and living patterns of human beings are changed. People are crazier towards fast food and many people are addicted to various addictions like cigarette smoking, alcohol etc. The daily routine of the people is also changed like late-night sleep, irregular timing of food. Hence this change causes the formation of free radicals. And free radical causes many diseases like hypertension, obesity, diabetes mellitus and cardiovascular diseases.

\section{Aim and Objectives}

1. To study the concept of free radicals, oxidative stress and antioxidants.

2. To establish a relationship between Amalaki as a Rasayan and their antioxidant potential.

\section{Material and Methods}

References were collected from Ayurveda classics and various journals. These references are analyzed logically, and results are drawn.

\section{Free Radicals -}

A free radical is a molecular species capable of independent existence that contains an unpaired electron in an atomic orbital. Many radicals are unstable and highly reactive. They can either donate an electron or accept an electron from other molecules, therefore behaving as oxidants. The most important oxygencontaining free radicals in many disease states are hydroxyl radical, hydrogen peroxide, hypochlorite, nitric oxide radical. Major targets of free radicals in the body are nucleic acids, proteins, and lipids.
Free radicals are produced during normal essential metabolic processes in the human body and from external sources such as exposure to X-rays, ozone, cigarette smoking, air pollutants and industrial chemicals.

\section{Oxidative Stress -}

Oxidative stress is essentially an imbalance between the production of free radicals and the ability of the body to counteract or detoxify their harmful effects through neutralization by antioxidants.

\section{Antioxidants -}

An antioxidant is a molecule stable, enough to donate an electron to rampaging free radical and neutralize it, thus reducing its capacity to damage. These antioxidants delay or inhibit cellular damage mainly through their free radical scavenging property. This low molecular weight antioxidant can safely interact with free radicals and terminate the chain reaction before vital molecules are damaged. Some antioxidants such as glutathione, uric acid is produced during normal metabolism in the body. Other lighter antioxidants are found in the diet. The principal micronutrients antioxidants are vitamin $\mathrm{C}, \mathrm{E}$ and beta carotene. The body cannot produce these micronutrients, so they must be supplied in the diet ${ }^{[3]}$.

\section{Mechanism of Antioxidants Action}

The first mechanism of action is a chain-breaking mechanism by which the primary antioxidant donates an electron to the free radical present in the system and the second mechanism involves the removal of reactive oxygen species (ROS) / nitrogen species inhibitors (secondary antioxidants) by quenching chain initiating catalyst [3].

\section{Vitamin C}

Vitamin $\mathrm{C}$ is a monosaccharide antioxidant found in both animals and plants. It cannot be synthesized in humans and must be obtained from the diet. It is a 
reducing agent and can reduce and thereby neutralize ROS such as hydrogen peroxide [3]. Images of stable molecule \& free radical and antioxidant are shown in image 1 and image 2 respectively.

\section{FREE RADICAL}

AND NORMAL MOLECULE
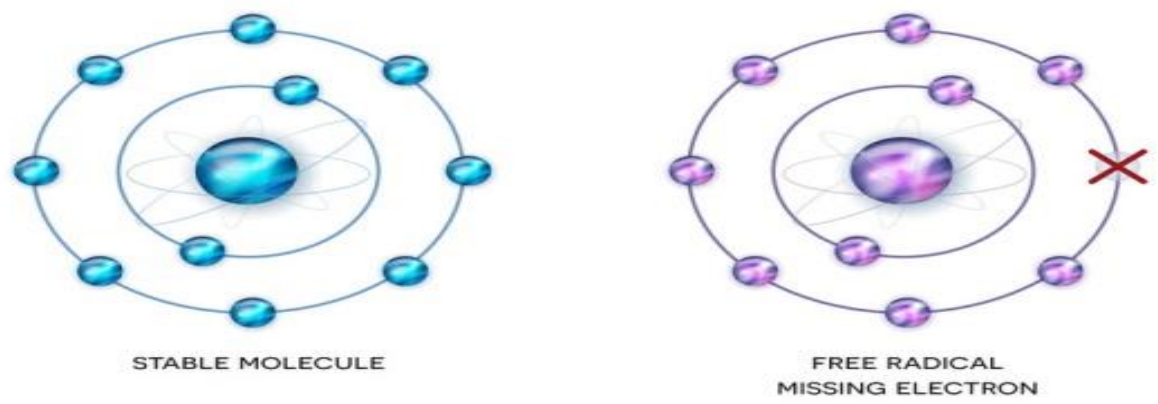

Image 1 - Stable \& free radical

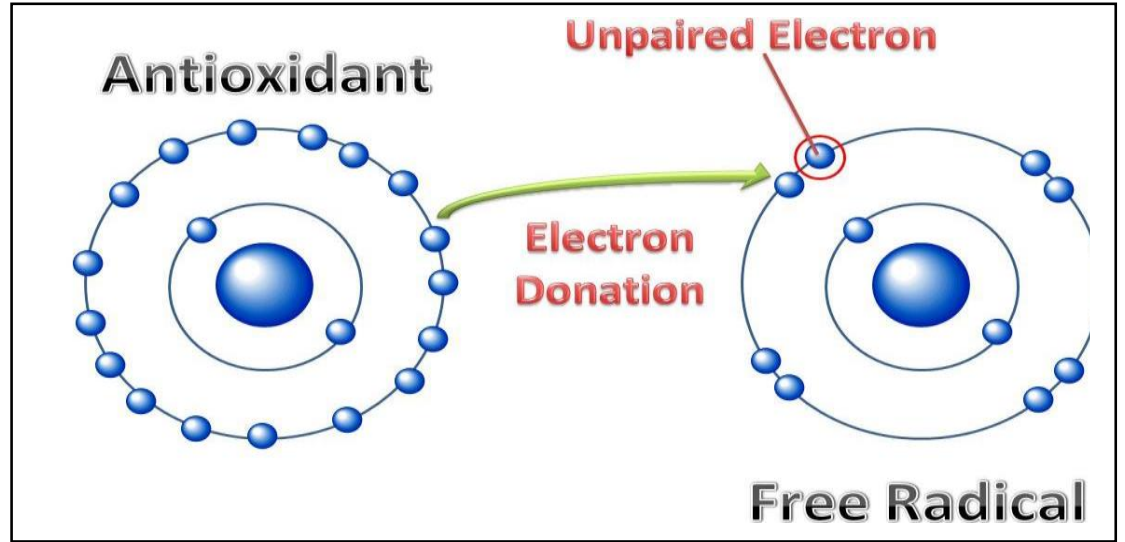

Image 2 - Antioxidant

\section{Amalaki}

Latin name - Embelica officinalis

Family - Euphorbiaceae

English name - Indian gooseberry

Sanskrit name - Amlaki, dhatri, shiva, amruta, sriphal.

Hindi name - Amla

Rasa-Madhur, amla, kashaya, katu, tikta.

Veerya - Sheeta

Vipak-Madhur

Guna - Ruksha

Doshaghnata - Tridoshnashak

Upyuktang - Fruit

\section{Functions of Amalaki}

In Ayurveda, Amalaki is indicated in the treatment of Kushtha, Gulma, Udavarta, Shoth, Pandu, Arsha, Grahanidosha, Puranvishamjwar, Hrudrog, Shirorog, Atisar, Arochak, Kasa, Prameha, Anaha, Vaivarnya, Vaiswarya, Tamak-Shwas, Chardi, Klaibya, Strotovibandha, Raktapitta. Amalaki fruit has many health benefits, and it is used as a principle in many ayurvedic preparations from ancient times. It is one of the best Rasayan ${ }^{[4]}$.

Amalaki is one of the medicinal plants and is a rich source of antioxidants. Now a day it is used in a wide number of forms like; health drinks, candy, pickles, 
chutney, jams etc. It is a nutritionally and medicinal-

ly important fruit due to its high vitamin $\mathrm{C}$ content.

Nutritive values of Amalaki per 100gm ${ }^{[5]}$

\begin{tabular}{l|l|l|l|l|l|}
\hline Macronutrients & \multicolumn{3}{l}{ Micronutrients } & Minerals \\
\hline Moisture & $81.8 \%$ & Vitamin C & $600 \mathrm{mg}$ & Calcium & $50 \mathrm{mg}$ \\
\hline Fibre & $3.4 \%$ & Vitamin B1 & $0.03 \mathrm{mg}$ & Phosphorus & $20 \mathrm{mg}$ \\
\hline Carbohydrates & $13.7 \mathrm{~g}$ & Vitamin B2 & $0.01 \mathrm{mg}$ & Iron & $1.2 \mathrm{mg}$ \\
\hline Proteins & $0.5 \mathrm{~g}$ & Vitamin B3 & $0.2 \mathrm{mg}$ & Folic acid & - \\
\hline Fat & $0.1 \mathrm{~g}$ & Vitamin A & $9 \mathrm{mg}$ & Energy & $58 \mathrm{kcal}$
\end{tabular}

\section{DISCUSSION}

Rasayan drugs are used for the maintenance of the health of a healthy person and to cure the diseased person. Also, they have antioxidants activity and suppress the activity of oxidative stressors, therefore reducing the production of free radicals. They create longevity, intellect, health, improve memory, strength, youthfulness, complexion, the luster of skin [6].

Antioxidants play an important role in age delaying and the prevention of diseases. In Ayurveda, different types of Rasayana formulations are described. Among them, Amalaki is the best Rasayan. It is tridoshahara. Due to the presence of amla rasa in Amalaki it is vatashamak; due to madhur rasa and sheeta guna, it is pittashamak and due to kashaya rasa \& ruksha guna it is kaphashamak ${ }^{[7]}$. As per modern science, it has the best antioxidant property which is due to the presence of vitamin $\mathrm{C}$.

\section{CONCLUSION}

Amalaki rasayan plays an important role as an antioxidant and thus it relives oxidative stress, hence helpful in the prevention of many diseases.

\section{REFERENCES}

1. K. Park. Concept of health and disease. Park's textbook of preventive $\&$ social medicine. $22^{\text {nd }}$ ed. Jabalpur, Bhanot publication, 2013. p. 13.

2. Dr Anant Ram Sharma, Vedotpatti Adhyaya - Sutra Sthan 1/7. Sushruta Samhita of Maharsi, Sushruta. Reprint. Varanasi, Chaukhambha Surbharti prakashan, 2000; p. 7

3. V. Lobo, A. Patil, N. Chandra; free radicals, antioxidants and functional foods: impact on human health;
Pharmacognosy reviews Wolterkluwer - Medknowpublications; www. Ncbi.nlm.nih.gov/pmc/ articles/ PMC3249911

4. Dr K.C. Chunekar. Haritakyadi Varga,20, 21, 39. Bhavprakash Nighantu of Bhavmishra, Reprint.Varanasi, Chaukhambha Bharti Academy. p.5,10

5. Dr Kashinath Samgandi, Aahardravya-nutritive values, Swasthvritta Sudha, $1^{\text {st }}$ edition. Jaipur, Ayurved Sanskrit Hindi Pustak Bhandar, 2015, p.636.

6. Jyotsna Gangasagre, Rasayan as antioxidants: An Ayurvedic perspective, international journal of Medicine and health profession research, 4(1), 2017, 31-34

7. Dr K.C. Chunekar. Haritakyadi Varga 39. Bhavprakash Nighantu of Bhavmishra, Reprint.Varanasi, Chaukhambha Bharti Academy. p.10

\section{Source of Support: Nil Conflict of Interest: None Declared}

How to cite this URL: Kshirsagar Shubhangi Sureshkumar et al: Role Of Amalaki Rasayan As An Antioxidant In Oxidative Stress. International Ayurvedic Medical Journal \{online\} 2021 \{cited October 2021\} Available from: http://www.iamj.in/posts/images/upload/2486_2489.pdf 